\title{
Susceptibility of Enterobacteriaceae from the Alpine Accentor Prunella collaris
}

\author{
J. TIMKO, V. KMEŤ
}

Department of Clinical Microbiology, Central Military Hospital, Ružomberok, Slovakia Institute of Animal Physiology, Slovak Academy of Sciences, Šoltésovej 4, Košice, Slovakia

Received August 2, 2002

Accepted April 28, 2003

\begin{abstract}
Timko J., V. Kmet V.: Susceptibility of Enterobacteriaceae from the Alpine Accentor Prunella collaris. Acta Vet. Brno 2003, 72: 285-288

Occurrence of bacterial species of the family Enterobacteriaceace and their susceptibility and minimum inhibitory concentrations $\left(\mathrm{MIC}_{90}\right)$ to 13 selected antimicrobial agents was studied in 22 faecal samples of the alpine accentor Prunella collaris. Alpine accentor is our main research avian model for the studying of the interaction between the comensal microflora and enviroment. We isolated E. coli, Serratia marscescens, Hafnia alvei, Citrobacter spp. and Morganella morgani strains. We found no resistance of E. coli and Serratia spp. The strains Serratia marcescens and Morganella morgani were $100 \%$ resistant to ampicilin, ampicilin+sulbactam and cefuroxim. Hafnia alvei showed resistance only to cefuroxim and Citrobacter spp. only to ampicilin. The results of our study have shown that in high altitude mountains - despite of deterioration of the environment - no selection pressure exists as yet of using antimicrobial agents and only intrinsic resistance of Enterobacteriaceae strains occurred to investigated antibiotics. This fact was documented by comparing the susceptibility of $E$. coli strains isolated from faecal samples of Prunella collaris with susceptibility of E. coli strains acquired from 218 patients from Central Military Hospital in 2001.
\end{abstract}

Susceptibility of Enterobacteriaceae, Prunella collaris, antibiotic resistance

An inevitable side effect of the use of antibiotics is the emergence and dissemination of resistant bacteria. Most retrospective and prospective studies show that after the introduction of an antibiotic not only the level of resistance of pathogenic bacteria, but also of commensal bacteria increases. Commensal bacteria play an important role in protection from enteric infections (Kmet et al. 1993), however, constitute a reservoir of resistance genes to (potentially) pathogenic bacteria, also. Their level of resistance is considered to be a good indicator for selection pressure by antibiotic use and for resistance problems to be expected in pathogens (Murray 1992). Monitoring the prevalence of resistance in indicator bacteria such as faecal Escherichia coli and enterococci in different populations of animals, patients and healthy humans, makes it feasible to compare the prevalence of resistance and to detect the transfer of resistant bacteria or resistance genes from animals to humans and vice versa (Van den Bogaard 2000).

The Alpine accentors were studied in the three geomorphologic areas: high altitude chains of the High and Low Tatra mountains, and the wintering site Malino Brdo, Great Fatra mountains. The summer study regions lie above the timber and dwarf pine line usually between 1800 and $2650 \mathrm{~m}$ above sea level. The habitats were dominated by alpine meadows and by rocky parts (Drgonová and Janiga 1989; Nakamura and Ueuma 1996).

Only few interactions exist between the alpine accentor and humans because this is a highly discrete bird whose sites of reproduction are far from any human influence. Perhaps only the development of ski resorts made it possible for this species to develop the wintering at altitude while giving access to him an easy food.

The aim of the study was to study the susceptibility of Enterobacteriaceae isolated from 
the alpine accentor Prunella collaris, to compare resistance of Enterobacteriaceae from alpine accentors with resistance of Enterobacteriaceae from clinical samples of hospitalized patients in Central Military Hospital in 2001 and to evaluate the influence of environment to susceptibility of Enterobacteriaceae.

\section{Materials and Methods}

Gram-negative strains of Enterobacteriaceae were isolated from 22 faecal samples of Prunella collaris and 218 strains $E$. coli were isolated from 218 patients (urinary tract infections $-57 \%$, wounds - $25 \%$, surgical samples- $7 \%$, others $-11 \%$ ).

Specimens of droppings were collected in sterile plastic containers and sent to the laboratory where they were inoculated on non-selective (Columbia blood agar, Oxoid) and selective medium (Endo agar, OXOID). All plates were incubated at $37^{\circ} \mathrm{C}$.

Isolates were identified to species (genus) level using standard laboratory methods for routine, and exact definitive identification of strains of family Enterobacteriaceae was made using ENTEROtest 24 (PLIVA Lachema). Configuration of tests enables a highly reliable identification without using other additional tests.

The susceptibility $\left(\mathrm{MIC}_{90}\right.$ ) of important strains of Enterobacteriaceae was determined by the MIDITECH automated colorimetric MIC reading for antimicrobial susceptibility testing ( $\mathrm{G}$ attring er et al. 2002). This system is a modification of the standard broth microdilution method that uses a 3-(4,5-dimetylthiazol-2-yl)-2,5-diphenyl tetrazolium bromide (MTT) dye for detecting viable bacteria.

\section{Results and Discussion}

In our study faecal samples were examined of Prunella collaris, a mountain bird living in the high altitude mountain environment. We obtained 34 strains of family Enterobacteriaceae. Total bacterial species are presented in Fig.1.

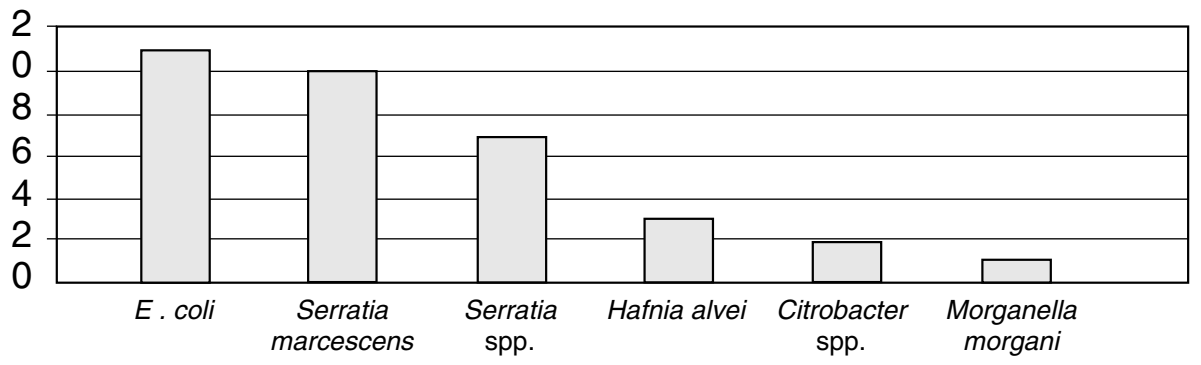

Fig. 1. Prevalence of Enterobacteriaceae strains isolated from 22 faecal samples of Prunella collaris

We found no resistance of E. coli and Serratia spp. The strains Serratia marcescens and Morganella morgani were $100 \%$ resistant to ampicilin, ampicilin+sulbactam and cefuroxim. Hafnia alvei showed resistance only to cefuroxim and Citrobacter spp. only to ampicilin.

The presented results are in good agreement with the intrinsic resistance of Enterobacteriaceae.

Susceptibility of E. coli strains isolated from faecal samples of Prunella collaris compared with that of E. coli strains of Central Military Hospital 218 patients in 2001 was excellent in all Prunella samples. It can be seen that the selection pressure of using antimicrobial agents changes the resistance. E. coli isolated from clinical samples of 218 patients had $42 \%$ resistance to ampicillin (92 strains), 24\% resistance to piperacilin (51 strains), $22 \%$ resistance to COT (48 strains), $16 \%$ to ciprinol (35 strains), $10 \%$ to cefotaxim (21 strains) and less than 5\% resistance to other seven antimicrobials (Fig. 2). The presented results are in agreement with resistance among 590 clinical $E$. coli isolates (Kme to vá et al. 2001). These autors observed that the highest resistance of $E$. coli was to ampicillin (46\%.) 
Table 1

Resistance of Enterobacteriaceae strains isolated from faecal samples of Prunella collaris to selected antimicrobial agents in per cent

\begin{tabular}{|l|c|c|c|c|c|c|}
\hline & E. coli & $\begin{array}{c}\text { Serratia } \\
\text { marcescens } \\
(10)\end{array}$ & $\begin{array}{c}\text { Serratia } \\
\text { spp. } \\
(7)\end{array}$ & $\begin{array}{c}\text { Hafnia } \\
\text { alvei } \\
(3)\end{array}$ & $\begin{array}{c}\text { Citrobacter } \\
\text { spp. } \\
(2)\end{array}$ & $\begin{array}{c}\text { Morganella } \\
\text { morgani } \\
(1)\end{array}$ \\
\hline AMP & $0 \mathrm{~b}$ & 100 & 0 & 0 & 100 & 100 \\
\hline A+IB & 0 & 100 & 0 & 0 & 0 & 100 \\
\hline PIP & 0 & 0 & 0 & 0 & 0 & 0 \\
\hline P+IB & 0 & 0 & 0 & 0 & 0 & 0 \\
\hline CXM & 0 & 100 & 0 & 100 & 0 & 100 \\
\hline CTX & 0 & 0 & 0 & 0 & 0 & 0 \\
\hline CAZ & 0 & 0 & 0 & 0 & 0 & 0 \\
\hline CPO & 0 & 0 & 0 & 0 & 0 & 0 \\
\hline CPM & 0 & 0 & 0 & 0 & 0 & 0 \\
\hline GEN & 0 & 0 & 0 & 0 & 0 & 0 \\
\hline AMI & 0 & 0 & 0 & 0 & 0 & 0 \\
\hline CIP & 0 & 0 & 0 & 0 & 0 & 0 \\
\hline COT & 0 & 0 & 0 & 0 & 0 & 0 \\
\hline
\end{tabular}

a - total number of isolates

$\mathrm{b}$ - value of resistance in $\%$

and the lowest resistance was found against two third generation cephalosporins, ceftazidime $(0.68 \%)$.

The normal bacterial flora in birds develops an effective defense mechanism against infection and illness. It is during times of illness, injury and excessive stress that the normal microflora, $\mathrm{pH}$ and digestive process can be effected. Examples of stress that can alter a birds physiological microflora populations in the gut are: feed or formula changes, poor nutrition, hatching, weaning, inadequate or close housing, shipping, excessive temperatures, exposure to pathogenic microorganisms or viruses, weakened immune system, and over exertion (McFarland 2000; Kleessen et al. 2000; Alverdy et al. 1998).

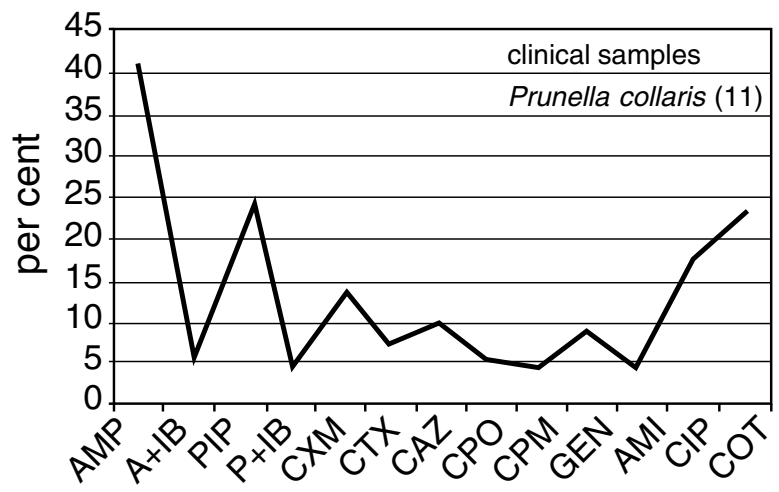

Fig. 2. Comparison of E. coli resistance to selected antimicrobial agents

AMP - ampicilin, A+IB - ampicilin + sulbactam, PIP - piperacilin, CXM - cefuroxim, CTX - cefotaxim, CAZ ceftazidim, CPO - cefpirom, CPM - meropenem, GEN - gentamycin, AMI - amikacin, CIP - ciprinol, COT trimetoprim + sulfonamid 
Prunella collaris is our main research avian model for the study of interactions between the comm;ensal microflora and enviroment. The results of our study confirm that in high altitude mountain environment - despite of deterioration of the environment - no selection pressure exists of using antimicrobial agents and only intrinsic resistance of Enterobacteriaceae strains occurred to investigated antibiotics.

\section{Citlivost' enterobakteriaceí u vrchárky červenkastej (Prunella collaris)}

Študovali sme výskyt bakteriálnych druhov čelade Enterobacteriaceae a ich citlivost a minimálnu inhibičnú koncentráciu na 13 vybraných antimikrobiálnych látok v 22 vzorkách trusu vrchárky červenkastej. Tento vysokohorský spevavec je našim hlavným vtáčím modelom v štúdiu vztahu medzi komenzálnou mikroflórou a životným prostredím. Izolovali sme nasledovné druhy baktérií: E. coli, Serratia marscescens, Hafnia alvei, Citrobacter spp. a Morganella morgani. Kmene E. coli a Serratia spp. boli citlivé na antibiotiká a kmene Serratia marcescens a Morganella morgani boli rezistentné na ampicilin, ampicilín+sulbaktám a cefuroxim. Hafnia alvei bola rezistnentná iba na cefuroxim a Citrobacter spp. len na ampicilín. Výsledky nášho štúdia ukázali, že vo vysokohorskom prostredí, napriek znečisteniu životného prostredia, neexistuje selekčný tlak antibiotík a preukázaná rezistencia u Enterobacteriaceae je iba prirodzenou rezistenciou na sledované antibiotiká. Tento fakt sme dokumentovali porovnaním citlivosti E. coli zo vzoriek Prunella collaris s citlivostou 218 kmeňov E. coli získaných z klinických vzoriek 218 pacientov ÚVN Ružomberok v roku 2001.

\section{Acknowledgements}

This study was supported by VEGA grant No. 2/1003/22. Authors are indebted to Dr. Marian Janiga PhD from Institute of High Amplitude Biology, University of Žilina, Slovakia for provision of the faecal samples from alpine accentor .

\section{References}

ALVERDY, J, STERN, E 1998: Effect of Imumunonutrition on virulence strategies in bacteria. Nutrition 14: 580594

DRGONOVA, N, JANIGA, M 1989: Nest structure of Alpine Accentors (Prunella collaris, Scop., 1769) in the Low Tatras. Biologia (Bratislava) 44: 983-993

GATTRINGER, R, NIKS, M, OSTERTAG, R, SCHWARZ, K, MEDVEDOVIC, H, GRANINGER, W, GEORGOPOULOS, A 2002: Evaluation of MIDITECH automated colorimetric MIC reading for antimicrobial susceptibility testing. J Antimicrob Chemother 49: 651-659

KLEESSEN, B, BEZIRTZOGLOU, E, MATTO J 2000: . Microbial Ecology in Health and Disease; 12 (4); Suppl. 2, 53-63

KMEŤ, V, STACHOVÁ, M, NEMCOVÁ, R, JONECOVÁ, Z, LAUKOVÁ, A 1993: Interaction of intestinal microflora with avian enteric pathogens. Acta Vet. Brno 62, Suppl 6, S87-S89

KMEŤOVÁ, M, SIEGFRIED, L, SABOL, M, BOGYIOVÁ, E, SANDORCINOVÁ, Z, KERESTESOVÁ, A, LIPTÁKOVÁ, A, MOLOKACOVÁ, M 2001: Incidence and transfer of antibiotic resistance in clinical isolates of Escherichia coli. Biologia (Bratislava) 56, Suppl. 9, pp. 55-59.

MURRAY, BE 1992: Problems and dilemmas of antimicrobial resistance. Pharmacotherapy 12: 86S-93S

McFARLAND, LV 2000: Microbial Ecology in Health and Disease 12 (4): 193-207

NAKAMURA, M, UEUMA, Y 1996: Comparative feeding ecology of the alpine accentor Prunella collaris on Mt. Hakusan and Mt. Norikura. J. Yamashina Inst Ornithol 28: 9-18

VAN DEN BOGAARD, AE, STOBBERINGH, EE 2000: Epidemiology of resistance to antibiotics. Links between animals and humans. Int J Antimicrob Agents 14: 327-335 